Uniwersytet Warmińsko-Mazurski w Olsztynie

Wydział Nauk Społecznych

Katedra Wczesnej Edukacji

tel. 604275848

e-mail: xzbyszek@me.com

\title{
Na kulturowej granicy Polski i Białorusi - inspiracje literackie i wartości artystyczne Śpiewnika domowego Stanisława Moniuszki
}

Słowa kluczowe: Moniuszko, Śpiewnik domowy, pieśń solowa, liryka wokalna, poezja

\section{Wstęp}

Twórczością Stanisława Moniuszki w literaturze zajmowano się już wielokrotnie. Powstało wiele monografii i artykułów. Wystarczy wymienić takich autorów jak: Zdzisław Jachimecki, [1983], Witold Rudziński [1957, 1988], Jan Prosnak [1980] czy Erwin Nowaczyk [1954], a wśród współczesnych badaczy: Stanisław Dąbek [2011], Jerzy Klechta [2013], a także Ryszard Wiesław Bednarek i Józef Maroszek [2011]. Jednakże dogłębną analizą tekstów literackich, które wykorzystywał w swoich pieśniach S. Moniuszko, dotychczas nie zajmowano się.

Wykonawcy utworów kompozytora do dziś są bardzo podzieleni w opiniach, jeśli chodzi o wartość muzyczną tych kompozycji. Autor artykułu, jako koncertujący śpiewak, solista (bas, basso-profondo), w swoim repertuarze ma ponad 25 spośród 364 pieśni tego kompozytora. Wciąż na nowo odkrywa piękno i głęboką retorykę tych utworów. Warto zatem przyjrzeć się, co na ten temat, przynajmniej w odniesieniu do wybranych pieśni, piszą teoretycy muzyki. 
Artykuł niniejszy należy traktować jako przyczynek do bardziej szczegółowych badań twórczości pieśniarskiej Moniuszki, zarówno pod względem muzycznym, jak i analizy tekstów. Wychodząc od wybranych wydarzeń z życia wybitnego kompozytora warto wskazać związki łączące jego twórczość z pograniczem kulturowym polsko-wschodniosłowiańskim, ponieważ Moniuszko urodził się na ziemiach wschodnich dawnej Rzeczpospolitej i był z tym terenem związany emocjonalnie. Dokonując analizy statystycznej utworów Moniuszki, przynajmniej z pewną dozą prawdopodobieństwa, można określić miejsce twórczości pieśniarskiej w całym jego dorobku kompozytorskim. Życiorysy autorów tekstów jego liryki wokalnej pozwalają określić literackie inspiracje tekstowe, które kompozytor preferował tworząc w znamiennej sytuacji politycznej (rozbiory Polski, dwa zrywy narodowe: powstanie listopadowe i styczniowe) oraz w specyficznym środowisku wschodnich ziem Polski, stanowiących styk trzech kultur: polskiej, litewskiej i białoruskiej.

Głównym przedmiotem uwagi w niniejszym opracowaniu są inspiracje literackie i wartości artystyczne Śpiewnika domowego S. Moniuszki. Podstawę teoretyczną i materiałową artykułu stanowią katalogi dzieł kompozytora, dostępne wydania utworów solowych i duetów oraz opracowania dotyczące tej problematyki. Zastosowane metody, analityczno-syntetyczna i statystyczna, pozwoliły autorowi rzetelnie przedstawić i ocenić zarówno udział utworów wielu poetów, jak i artystyczną wartość dorobku kompozytorskiego.

\section{Między Mińskiem, Wilnem i Warszawą - życie i twórczość Stanisława Moniuszki}

Po trzech rozbiorach Polski, wiek XIX był dla wielu Polaków czasem wygnania, ale też i zrywów narodowych. Ich największe przejawy to: powstanie listopadowe (1830-1831) i powstanie styczniowe (1863-1864) [Davies 1991, t. I 669; t. II 113-210]. Po upadku powstania listopadowego, a następnie styczniowego, na ziemiach, znajdujących się pod zaborem rosyjskim, w warunkach systematycznego niszczenia przez władze zaborcze tożsamości narodowej, żył i tworzył, pochodzący z patriotycznej rodziny ziemiańskiej Stanisław Moniuszko [Dziębowska 2000, 303, 305]. Postawę ideową kompozytora Elżbieta Dziębowska określa jako romantyczno-pozytywistyczną: „Z romantyzmem wiązała go wrodzona wrażliwość, emocjonalne podejście do otaczającego świata, głęboka wiara w istnienie Boga-Stwórcy, z pozytywizmem - racjonalistyczne myślenie, kult nauki i pracy". Potwierdza to również jego troska o rozbudzenie życia muzycznego Wilna, o kształcenie 
muzyków czy charakter jego twórczości. Dzięki sile swego talentu stał się najwybitniejszym przedstawicielem polskiej muzyki wokalnej XIX wieku [Dziębowska 2000, 303, 305].

S. Moniuszko urodził się 5 maja 1819 w majątku Ubiel w mińskiej guberni. Kształceniem muzycznym początkowo zajmowała się matka Elżbieta. Na jego rozwój mieli wpływ również stryjowie: Dominik, Kazimierz i Józef. W dworku w Ubieli, w dużej mierze za ich przyczyną, grano scenki teatralne i śpiewano powszechnie znane pieśni, m.in. ze Śpiewników historycznych J. U. Niemcewicza [Dziębowska 2000, 303]. Po przeprowadzce rodziny Moniuszków do Warszawy (1827 r.) uczył się w gimnazjum pijarów, a gry na fortepianie - u Augusta Freyera. W 1830 roku Moniuszkowie powrócili do Mińska, gdzie Stanisław pobierał prywatne lekcje fortepianu u Dominika Stefanowicza. W domu Moniuszków odbywały się wieczory muzyczne, bywali pisarze i nauczyciele [Dziębowska 2000, 303, 305].

W 1837 r. Moniuszko wyjechał na studia do Berlina, gdzie pod kierunkiem Carla Friedricha Rungenhagena, dyrektora Towarzystwa Muzycznego „Singakademie”, prywatnie uczył się harmonii, kontrapunktu, instrumentacji i dyrygentury. Odbywał także praktykę, prowadząc chóry i akompaniując śpiewakom, poznawał repertuar operowy, oratoryjny i symfoniczny, proces przygotowywania dzieł do wystawienia oraz technikę dyrygowania, biorąc udział w próbach prowadzonych przez Carla Friedricha Rungenhagena i goszczącego wówczas w Berlinie Gaspara Spontiniego. W Berlinie powstały pieśni: Trzy śpiewy (1838) do słów Mickiewicza (Sen, Niepewność i Pieszczotka), a następnie (1839) dwie kolejne: Trzech budrysów i Rozmowa, również do słów Mickiewicza. E. Dziębowska odnotowała, że nie były to jego pierwsze kompozycje, bowiem już wcześniej pisał pieśni i utwory fortepianowe [2000, 304].

W 1840 roku Moniuszko wrócił do kraju. Kompozytor ożenił się z Aleksandrą Müllerówną i zamieszkał z nią w Wilnie. Tam został prywatnym nauczycielem gry na fortepianie oraz obją stanowisko organisty w tamtejszym kościele św. Jana. W Wilnie zorganizował amatorski zespół chóralny, z którym podczas kilku miesięcy jego istnienia wykonał z towarzyszeniem doraźnie zorganizowanej orkiestry Requiem Wolfganga Amadeusza Mozarta oraz fragmenty oratoriów Stworzenie świata Josepha Haydna i Paulus Felixa Mendelssohna-Bartholdy'ego. W Wilnie powstały liczne pieśni, które kompozytor gromadził z zamiarem kompleksowego wydania. W 1843 r. wydał pierwszy tom Śpiewnika domowego, pozytywnie zrecenzowany przez Ignacego J. Kraszewskiego. W 1854 roku założył w Wilnie Towarzystwo im. św. Cecylii, którego członkowie-amatorzy dawali pod jego batutą dwa razy w roku publiczne koncerty [Dziębowska 2000, 304]. 
W roku 1858 Moniuszko, wraz z rodziną, przeniósł się do Warszawy. W 1859 został pierwszym dyrygentem Opery Polskiej w Teatrze Wielkim w Warszawie. Podczas piętnastu niemal lat pracy na tym stanowisku przygotował i wystawił kolejno wszystkie swoje opery. Prowadził też chóry w kościołach warszawskich. Wykładał harmonię, kontrapunkt i kompozycję oraz prowadził zespół chóralny w Instytucie Muzycznym w Warszawie [Dziębowska 2000, 304]. Odbywał też podróże artystyczne m.in. do St. Petersburga (1842, 1849, 1856, 1870), gdzie nawiązał znajomości z wybitnymi muzykami rosyjskimi, m.in. z Michaiłem Glinką, Aleksandrem Dargomyżskim, Cezarem Cui czy Aleksandrem Sierowem [Prosnak 1980, 79].

S. Moniuszko zmarł nagle na atak serca 4 czerwca 1872 r. w Warszawie. Pochowany został na Cmentarzu Powązkowskim w Warszawie [Dziębowska 2000, 305].

Etapy jego życia można zamknąć w następujących ramach periodyzacyjnych:

- 1819-1837 - dzieciństwo i młodość - między Ubielą, Warszawą i Mińskiem,

- 1837-1840 - studia w Berlinie,

- 1840-1858 - okres wileński,

- 1858-1872 - okres warszawski.

Śpiewnik domowy S. Moniuszki ukazywał się kolejno w latach (informacja o wydawcy lub wydawnictwie ma charakter kluczowy): tom I - 1843, tom II - 1845 lub 1946, tom III - 1851 (wyd. Klukowski, Wilno), tom IV - 1855, tom V - 1858, tom VI - 1859 (wyd. Zawadzki, Wilno), tom VII - ok. 1873, tom VIII - 1908, tom IX - 1908, tom X - 1909, tom XI - 1908 i tom XII - 1910 (wyd. S.I.M., Warszawa) [Nowaczyk 1954, 307-310]. Zatem sześć tomów zostało wydanych za życia kompozytora, sześć po jego śmierci.

Warto przyjrzeć się w tym miejscu pieśniarskiej twórczości Moniuszki na tle innych gatunków muzycznych, które stanowią cały jego dorobek kompozytorski. Tabela 1 zawiera ilościowe i procentowe zestawienie dzieł Moniuszki w podziale gatunkowym.

Trudno zestawiać obok siebie wielkie dzieła instrumentalno-wokalne, takie jak opery i utwory kameralne oraz pieśni. Niemniej jednak powyższe zestawienie odzwierciedla upodobania i ogólne tendencje w dorobku kompozytorskim Moniuszki. Dominują utwory wokalne, stanowiące ponad 65\% ogólnej liczby dzieł kompozytora. Drugie miejsce zajmują utwory instrumentalne. I choć Moniuszko nazywany jest ojcem polskiej opery narodowej, to utwory wokalno-instrumentalne znajdują się dopiero na trzecim miejscu, jeśli chodzi o ich liczbę. 
Tabela 1. Analiza frekwencyjna kompozycji S. Moniuszki

\begin{tabular}{|c|c|c|c|c|c|c|c|}
\hline \multirow{2}{*}{$\begin{array}{c}\text { Suma } \\
\text { utworów } \\
\text { analizowanych }\end{array}$} & \multicolumn{3}{|c|}{$\begin{array}{c}\text { Kompozycje } \\
\text { instrumentalne }\end{array}$} & \multicolumn{2}{c|}{$\begin{array}{c}\text { Kompozycje } \\
\text { wokalno- } \\
\text {-instrumentalne }\end{array}$} & \multicolumn{2}{|c|}{ Utwory wokalne } \\
\cline { 2 - 8 } & $\mathrm{A}$ & $\mathrm{B}$ & $\mathrm{C}$ & $\mathrm{D}$ & $\mathrm{E}$ & $\mathrm{F}$ & $\mathrm{G}$ \\
\hline 610 & 93 & 24 & 19 & 39 & 36 & 364 & 35 \\
\hline $100 \%$ & $15,25 \%$ & $3,93 \%$ & $3,12 \%$ & $6,39 \%$ & $5,90 \%$ & $59,67 \%$ & $5,74 \%$ \\
\hline 364 & \multicolumn{3}{|c|}{136} & \multicolumn{2}{c|}{75} & \multicolumn{2}{|c|}{399} \\
\hline $100 \%$ & \multicolumn{3}{|c|}{$22,30 \%$} & \multicolumn{2}{c|}{$12,29 \%$} & \multicolumn{2}{c|}{$65,41 \%$} \\
\hline
\end{tabular}

A - utwory fortepianowe (w tym transkrypcje fort., transkrypcje fort. na 4 ręce i opracowania na fort.)

B - organowe opracowania pieśni religijnych

C - utwory orkiestrowe, kameralne i balety

D - opery, operetki, muzyka do sztuk teatralnych

E - utwory oratoryjno-kantatowe (rel. i świeckie) i pieśni z tow. orkiestry

F - na głos solo i duety (rel. i świeckie)

G - chóralne (rel. i świeckie; w tym msze)

Źródła: [Duszyk 2000, 307-327]; segregacja i obliczenia własne autora artykułu.

Wszystkie dzieła Moniuszki autor artykułu podzielił następująco:

- utwory fortepianowe ( $\mathrm{w}$ tym transkrypcje fortepianowe, transkrypcje fortepianowe na 4 ręce i opracowania na fortepian),

- organowe opracowania pieśni religijnych,

- utwory orkiestrowe, kameralne i balety,

- opery, operetki oraz muzyka do sztuk teatralnych,

- religijne i świeckie utwory oratoryjno-kantatowe oraz pieśni z towarzyszeniem orkiestry,

- religijne i świeckie pieśni na głos solo oraz duety,

- religijne i świeckie pieśni chóralne (w tym msze).

Ponad połowę, bo prawie 60\% wszystkich dzieł Moniuszki, stanowią pieśni solowe i duety. Autor doliczył się łącznie 364 pieśni. Wśród nich znalazły się zarówno solowe pieśni świeckie i religijne, jak i duety.

\section{Literackie inspiracje Śpiewnika domowego - autorzy tekstów pieśni Moniuszki}

E. Dziębowska zauważa, że Moniuszko komponował głównie do tekstów współczesnych sobie poetów polskich, zwłaszcza z kręgu wileńskiego: Adama Mickiewicza, Władysława Syrokomli, Jana Czeczota, Antoniego E. Odyńca, Ignacego J. Kraszewskiego, także Jana Kochanowskiego; sporadycznie sięgał po teksty poetów francuskich (Pierre-Jean de Béranger, Casimir Delavigne, 
Victor Hugo), niemieckich (Johann.W. von Goethe), angielskich (Wiliam Szekspir, Walter Scott), rosyjskich i innych [Dziębowska 2000, 331].

Autor niniejszego artykułu doliczył się łącznie 97 twórców i źródeł tekstów pieśni Moniuszki. W tej liczbie jest 42 autorów, po których teksty sięgał więcej niż jeden raz i 55 twórców będących autorami słów tylko jednej kompozycji. Dodać też trzeba, że wśród tych 97 autorów tekstów jest zaledwie 20 poetów z zagranicy oraz dwa źródła biblijne (teksty z Psałserza Dawida ${ }^{1}$ oraz Ewangelia według św. Mateusza²).

Najpierw zatem należy przedstawić wybranych polskich autorów tekstów pieśni, które znalazły się w Śpiewniku domowym S. Moniuszki. W tym celu zostaną zaprezentowane krótkie notki biograficzne, w których wskazane jest miejsce pochodzenia i działalności danego twórcy (głównie chodzi o tych poetów, których teksty były wykorzystane wielokrotnie) ${ }^{3}$. S. Moniuszko najczęściej, bo aż 21 razy, sięgał po teksty wybitnego poety Adama Mickiewicza $(1798-1855)^{4}$. Do tej liczby trzeba zapewne jeszcze dodać Mignon J. W. Goethego w tłumaczeniu A. Mickiewicza. Teksty Władysława Syrokomli $^{5}$ (Ludwik Władysław Franciszek Kondratowicz, 1823-1862) Moniuszko wykorzystał komponując 19 pieśni. Wiersze Jana Czeczota ${ }^{6}$ (1796-1847) znajdziemy w 17 utworach ze Śpiewnika domowego. Po 14 pieśni skomponowanych zostało do tekstów Stefana Witwickiego ${ }^{7}$ (1801-1847) i Edmun-

1 W tłumaczeniu Franciszka Karpińskiego i Jana Chęcińskiego; do tych tekstów Moniuszko napisał osiem utworów.

2 Pieśń Ojcze nasz.

3 Krótkie noty biograficzne wybranych autorów tekstów zostały sporządzone na podstawie biogramów zaczerpniętych z Wielkiej Encyklopedii Powszechnej PWN. Fakt wykorzystania tekstów danego poety więcej niż dwukrotnie pozwala przypuszczać, że kompozytor znał tego twórcę lepiej lub częściej miał z nim kontakt.

4 Adam Mickiewicz urodził się w Nowogródku. Kilka lat (1824-1829) spędził w Rosji (Odessa, Moskwa, Petersburg). Studiował w Uniwersytecie Wileńskim, potem uczył w szkole powiatowej w Kownie. Od 1832 r. mieszkał w Paryżu, następnie w Rzymie. Zmarł w Stambule.

5 Władysław Syrokomla urodził się w Smolhowie (obwód miński). Kształcił się w prowadzonej przez dominikanów szkole w Nieświeżu, a później w Nowogródku. Dzierżawił wieś Załucze, później Borejkowszyznę pod Wilnem, mieszkał tė̇ w Wilnie, gdzie zmarł.

6 Jan Czeczot urodził się w folwarku Maluszyce w gminie Rajce w woj. nowogródzkim. Kształcił się w powiatowej szkole dominikańskiej w Nowogródku. Studiował na Cesarskim Uniwersytecie Wileńskim, studia te przerwał. Za działalność konspiracyjną został zesłany do Ufy, następnie przeniesiony do Tweru i do Lepla. Był przyjacielem Adama Mickiewicza. Zmarł w Druskiennikach. Trzy teksty tego poety (w pieśniach Moniuszki) zostały przetłumaczone na język rosyjski przez W.G. Bieniediktowa.

7 Stefan Witwicki urodził się w Janowie na Podolu. Ukończył Liceum Krzemienieckie. Od 1822 roku przebywał w Warszawie. Przyjaźnił się także z młodymi artystami: Fryderykiem Chopinem, Maurycym Mochnackim, Bohdanem Zaleskim i Antonim Edwardem Odyńcem. Zmarł w Rzymie na ospę. 
da Wasilewskiego ${ }^{8}$ (1814-1846). Siedem kompozycji zawiera wiersze Kazimierza Brodzińskiego ${ }^{9}$ (1791-1835), Jana Prusinowskiego ${ }^{10}$ (1818-1892) i Antoniego Kolankowskiego ${ }^{11}$ (1825-1881); sześć: Józefa Korzeniowskiego ${ }^{12}$ (1797-1863), Józefa Ignacego Kraszewskiego ${ }^{13}$ (1812-1887) i Marii Ilnickiej14 (1825-1897); pięć: Juliana Korsaka (1806 lub 1807-1855), Edwarda Żeligowskiego (pseud. Antoni Sowa) (1816-1864) i Włodzimierza Wolskiego (1824-1882); cztery: Jana Kochanowskiego (1530-1584), Szymona Konopackiego (1790-1884), Stanisława Jachowicza (1796-1857), Antoniego Edwarda Odyńca (1804-1885), Teofila Lenartowicza (1822-1893), Jana Zachariasiewicza (1823-1906) i Aleksandra Michaux (pseud. Miron; 1839-1895); trzy: Józefa Bohdana Zaleskiego (1802-1886), Ludwika Sztyrmera (pseud. Eleonora Stürmer, Styrner, Sztyrmer) (1809-1886), Placyda Jankowskiego (pseud. John of Dycalp; 1810-1872) i Piotra Maszyńskiego (1855-1934); dwie: Adama Stanisława Krasińskiego (1714-1800), Franciszka Dionizego Kniaźnina (1750-1807), Aleksandra Chodźki (1804-1891), Wincentego Pola (1807-1872), Lucjana Siemieńskiego (1807-1877), Justyna Wojewódzkie-

8 Edmund Wasilewski urodził się w Rogoźnie w Lubelskiem. Znany jako poeta Wolnego Miasta Krakowa, uznawany za najwybitniejszego krakowskiego poetę przed Stanisławem Wyspiańskim. Od lat dziecięcych związany z Krakowem, gdzie też zmarł.

9 Kazimierz Brodziński, urodzony w Królówce koło Bochni, rozpoczął naukę w wiejskiej szkółce trywialnej w Lipnicy Murowanej, później przeszedł do szkoły w Tarnowie. Od 1814 r. mieszkał w Warszawie. Po upadku powstania listopadowego przebywał w Krakowie, na krótko wyemigrował, ale od 1834 zamieszkał w Warszawie. Zmarł w Dreźnie.

10 Jan Prusinowski urodził się na Wołyniu. Ukończył gimnazjum w Żytomierzku. Zesłany do Symbirska. W Rosji studiował prawo, które ukończył w 1850 w Moskwie. Zmarł w Żytomierzku.

11 Antoni Kolankowski urodził się w Suwałkach. Młodość spędził na Wileńszczyźnie. Od ok. 1870 r. pewien czas mieszkał w Warszawie. Przyjaźnił się z W. Syrokomlą. Zmarł w Suwałkach.

12 Józef Korzeniowski urodził się w Brodach. Był uczniem infimy w Zbarażu, do drugiej klasy chodził w Czerniowcach. Był absolwentem, a później profesorem literatury polskiej w Liceum w Krzemieńcu. Krótki czas mieszkał w Warszawie. Był dyrektorem gimnazjum w Charkowie. Wykładał także filologię klasyczną na uniwersytecie w Kijowie. Przed śmiercią wyjechał do Drezna.

13 Józef Ignacy Kraszewski urodził się w Warszawie. Rodzice mieszkali na Grodzieńszczyźnie w majątku Dołhe koło Prużan. Pod opieką babki Zofii Malskiej i prababki Konstancji Nowowiejskiej wychowywał się w Romanowie w powiecie włodawskim (obecnie powiat bialski). Kształcił się w szkole wydziałowej w Białej Podlaskiej, zwanej wówczas Akademią Bialską, w szkole wojewódzkiej w Lublinie, w gimnazjum w Swisłoczy. Rozpoczął studia na Wydziale Lekarskim Uniwersytetu Wileńskiego, wkrótce przeniósł się na literaturę. Często zmieniał miejsca zamieszkania: Dołhe, później Wołyń (Omelno, Gródek, Hubin koło Łucka, Żytomierz), Warszawa, Drezno, Lwów, Kraków, Berlin, Lipsk, San Remo, czy Austria i Szwajcaria. Zmarł w Genewie.

14 Autorka komedii, wierszy i powieści Maria Ilnicka całe życie była związana z Warszawą. Tłumaczyła między innymi wiersze Waltera Scotta i Johanna Goethego. 
go (1820-1883), Antoniego Pietkiewicza (pseud. Adam Pług; 1823-1903), Józefa Grajnerta (1831-1910) oraz Maksymiliana Radziszewskiego i bliżej nieznanego autora o nazwisku Sakowski.

Po jednej pieśni Moniuszko napisał do tekstów następujących autorów: Jana Chodźki (1777-1851), Jana Nepomucena Kamińskiego (17771855), Franciszka Morawskiego (1783-1861), Antoniego Malczewskiego (1793-1826), Tomasza Zana (1796-1855), Tymona Zaborowskiego (17991828), Franciszka Kowalskiego (1799-1862), Józefa Massalskiego (18001845), Ksawerego Godebskiego (1801-1869), Michała Grabowskiego (18041863), Aleksandra Grozy (1807-1875), Lucjana Siemieńskiego (1807-1877), Jana Nepomucena Jaśkowskiego (1807-1882), Gustawa Zielińskiego (18091881), Antoniego Czajkowskiego (1816-1873), Seweryny Pruszakowej z Żochowskich (Seweryna Duchińska; 1816-1905), Wacława Szymanowskiego (1821-1886), Aleksandra Walickiego (1826-1893), Jana Aleksandra Fredry (1829-1891), Bruno Bielawskiego (1831-1861), Mieczysława Romanowskiego (1833-1863), Józefa Szujskiego (1835-1883), Adama Asnyka (1838-1897), Adama Maszewskiego (1844-1901), Józefa Teodora Stanisława Kościelskiego (1845-1911) oraz Kazimierza Laskowskiego (1861-1913), a także bliżej nieznanych autorów: Teofila Benisławskiego, Henryka Dammasa, Walentego Grzymałowskiego, J. Januszkiewicza, E. Kruse, B. Morgenszterna, J. Moroza, Stanisława Rosołowskiego, ks. Wojniłowicza, Zborowskiego, Stanisława F. Żukowskiego oraz Franciszka Żylińskiego. Jest też pieśń, której autor posiadał pseudonim Safo (podany w nagłówku), z kolei inna jest oznaczona inicjałami F.S.

Jak już wspomniano powyżej, wśród autorów tekstów pieśni Moniuszki odnajdujemy 20 poetów obcego pochodzenia. W ogólnej liczbie 364 pieśni i duetów 40 stanowią utwory do tekstów autorów z zagranicy. Są nimi: Rosjanie - Władimir Grigorjewicz Bieniediktow ${ }^{15}$ (1807-1873), Iwan Kozłow $^{16}$ (1779-1840), Nestor Wasiliewicz Kukolnik (1809-1868); poeci francuscy - Pierre-Jean de Béranger ${ }^{17}$ (1780-1857), Marceline Desbordes-Valmore $^{18}$ (1786-1859), Casimir Delavigne (1793-1843), Paul de Kock (1793-1871), Victor Hugo ${ }^{19}$ (1802-1885), Alfred Des Essarts (1811-1893), Adolphe d'Ennery (1811-1899); Anglicy - William Szekspir20 (1564-1564),

\footnotetext{
15 Moniuszko napisał pięć pieśni do jego tekstów.

16 W tłum. na język polski S.A. Lachowicz.

17 Osiem pieśni, w tym tłumaczenia polskie Władysława Syrokomli (3), Leopolda Borowskiego, Maksymiliana Radziszewskiego.

18 Dwa teksty w tłum. pol. Maksymiliana Radziszewskiego.

19 Trzy pieśni, wśród nich jedna w tłum. pol. Justyna Wojewódzkiego.

20 Jedna pieśń w tłum. K. Ostrowskiego.
} 
Walter Scott21 (1771-1832), George Byron (1788-1824), dwóch czołowych przedstawicieli niemieckiego romantyzmu w literaturze - Johann Wolfgang von Goethe ${ }^{22}$ (1749-1832), Heinrich Heine ${ }^{23}$ (1797-1856); jeden poeta białoruski - Wincenty Dunin-Marcinkiewicz (1808-1884) oraz hiszpański baryton, osiadły w Wilnie Józef Achilles Bonoldi (1821-1871). Do tej listy dopisuja się także bliżej nieznani - Ch. Mollevoye ${ }^{24}$, G. Lemoine, L. de Perthées. Wśród źródeł tekstowych pieśni Moniuszki odnotować również należy teksty z Psatserza Dawida ${ }^{25}$ oraz cytat z Ewangelii wg św. Mateusza (Ojcze nasz).

Polaryzuje się zatem pogląd na to, jakimi intencjami czy też jakim kryterium kierował się S. Moniuszko dokonując wyboru tekstów do Śpiewnika domowego. Natchnienie czerpał, poza kilkoma wyjątkami, w poezji romantycznej. Do tych wyjątków należą utwory: Williama Szekspira $^{26}$ (1564-1564), Jana Kochanowskiego (1530-1584), Adama Stanisława Krasińskiego (1714-1800) i Franciszka Dionizego Kniaźnina (1750-1807). Większość autorów tekstów pieśni kompozytora związana była z ziemiami wschodnimi dawnej Rzeczpospolitej.

\section{Artystyczne wartości wybranych pieśni Moniuszki}

W Encyklopedii muzycznej PWM czytamy: „Talent Moniuszki przejawia się przede wszystkim w swoistej melodyce jego pieśni będącej jakby kwintesencją polskości, wyrosła ona bowiem z uogólnienia polskiego folkloru w szerokim tego słowa znaczeniu (pieśń ludowa, mieszczańska, popularna, przekazana tradycją) bez preferowania wybranego regionu; równie często występują w nich rytmy poloneza, mazura, kujawiaka jak i krakowiaka" [Dziębowska 2000, 331]. Śpiewność jego pieśni można przyrównać raczej do rosyjskiej liryki wokalnej (romansu), niż do typowej dla niemieckiego romantyzmu Lied. E. Dziębowska stwierdziła, że mogą też być powiązanie z białoruską pieśnią ludową lub niemiecką pieśnią mieszczańską, bowiem „kresy pod względem kulturowym stanowiły swoisty konglomerat narodowości

\footnotetext{
21 Cztery pieśni w przekładzie Antoniego Edwarda Odyńca.

22 Cztery pieśni w tłum. pol. Adama Mickiewicza, Kazimierza Brodzińskiego, T. Makuszewskiego.

23 Tekst w tłum. pol. Antoniego Edwarda Żeligowskiego (pseud. Antoni Sowa).

24 Tekst w tłum. pol. Zofii Jachimeckiej.

25 Osiem utworów w tłumaczeniu Franciszka Karpińskiego i Jana Chęcińskiego.

26 Jedna pieśń w tłum. K. Ostrowskiego.
} 
zamieszkujących te tereny". Moniuszko dążył do stworzenia powszechnego repertuaru śpiewaczego. Dlatego dbał o prostotę tych pieśni. Jak sam uzasadniał, w prospekcie zapowiadajaccym wydanie pierwszego zeszytu Śpiewnika domowego: „to co jest narodowe, krajowe, miejscowe, co jest echem dziecinnych naszych przypomnień, nigdy mieszkańcom ziemi, na której się urodzili i wzrośli podobać się nie przestanie" [Dziębowska 2000, 331]. Tę wypowiedź zapewne też tłumaczy fakt, że inspirację czerpał głównie u autorów pochodzących z kresów wschodnich.

Pod względem gatunkowym Śpiewnik domowy zawiera piosnki sielskie i dumki, romanse i ballady, lirykę miłosną i pieśni dramatyczne, śpiewy i dumy historyczne, piosenki taneczne i wojenne. Moniuszko komponował zwykłe pieśni zwrotkowe lub też zwrotkowe z refrenem (np. Stary kapral, Znasz-li ten kraj, Pieśń żeglarzy). Czasem stosuje w nich elementy techniki wariacyjnej. W pieśniach o większych rozmiarach występuje schemat AB lub ABA. Jak podkreśla Dziębowska, „(...) spopularyzowaniu pieśni, adresowanej wszakże do amatorów, sprzyjała kantylenowa melodyka, jednorodna rytmika, prosta harmonia i łatwy akompaniament fortepianowy o bardziej zróżnicowanej fakturze w pieśniach wieloczęściowych; często pieśn obramowana jest krótkim fortepianowym preludium i postludium". W pieśniarskiej twórczości kompozytora wyróżniają się ballady, z ich rozbudowaną formą (np. Czaty, Świtezianka). Sprawnie operuje w nich zmianami agogicznymi i dynamicznymi czy kontrastami między epicką narracją, a fragmentami dramaturgicznymi i lirycznymi (np. Dziad $i$ baba). Pieśni Moniuszki, mimo prostoty środków muzycznych, świadczą o jego inwencji melodycznej i umiejętności oddania dramaturgii tekstu słownego w konstrukcji melodii. Dlatego zwraca się uwagę na ich wysoką rangę artystyczną [Dziębowska 2000, 331].

Zdaniem Witolda Rudzińskiego, „Moniuszko był mistrzem pieśni wyrazowych, w których stawiał wykonawcom wysokie wymagania interpretacyjne” [Rudziński 1957, 143]. Jego pieśni „są zawsze ściśle zespolone z tekstem, kompozytor wiernie dostosowuje się do nastroju, obrazów i przeżyć opisanych w wierszu, liczy się z jego formą. Umiejętnie dobiera melodię do swoich pieśni; jeśli wymaga tego sytuacja, umie swoją pieśń rozwinąć, uniezależnić od zewnętrznych rygorów poezji”. Sama warstwa fortepianu często „uzupełnia narrację, wzbogaca nastrój wiersza, wydobywa zeń nieoczekiwane nastroje i treści" [Rudziński 1983, 43, 143].

Z kolei Zdzisław Jachimecki zwraca uwagę na wartości artystyczne konkretnych pieśni Moniuszki. Wskazuje na bogactwo środków artystycznego wyrazu, szczególnie w warstwie akompaniamentu, w balladzie Świtezianka (do słów Mickiewicza) [1983, 43]. Zauważa też, że w Przaśniczce (sł. Jana 
Czeczota) kompozytor doprowadził do doskonałości „formę i środki charakterystyki muzycznej. O pierwszej można powiedzieć, że ani jednej nutki nie zniosłaby więcej, tak doskonale jest utworzona, ani jednej nie można by tė̇ ujacć bez narażenia jej na szwank" W utworze tym Moniuszko perfekcyjnie podzielił zadania liryczne i opisowe pomiędzy głos solowy i akompaniament fortepianu. „Melodia wokalna jest tu uroczym konturem poezji zacisznej, rodzajowej; akompaniament zaś jest tu realistycznym wtórem lirycznego nastroju i nie uczestniczy w pieśni żadnym czynnikiem uczuciowym, tylko samym mechanicznym ruchem". Z. Jachimecki podkreśla, iż Moniuszko w Przaśniczce „stanął na poziomie doskonałości arcydzieł Schuberta” [Jachimecki 1983, 49-50].

Pieśń Znasz-li ten kraj (do słów Goethego w tłumaczeniu Mickiewicza) Jachimecki zestawia z pieśniami innych kompozytorów napisanymi do tego wiersza (Beethoven, Schubert, Schumann). W tej pieśni Moniuszko położył „cały nacisk na wyraz liryczny. Cudem melodycznego pomysłu wywołał nastrój o przenikającej intensywności, wyczarował fatamorganę świata o najwyższym uroku i poezji”. Dalej Jachimecki pisze, że „pieśń ta jest arcyutworem pod względem formy, pojętej nie tylko tematycznie, ale także co do rozkładu natężenia dźwięków”, dodaje też, że „w utworze tym talent pieśniarski Moniuszki stanął u szczytu rozwoju". Natomiast w melodii pieśni $O$ matko moja (sł. Jana Prusinowskiego) badacz podkreśla „porywający żar wyrazu i nadzwyczaj szlachetny rysunek". W Starym kapralu (sł. P.-J. de Béranger) akompaniament fortepianu, poprzez posępne akordy naśladujące rytm plutonu egzekucyjnego, w sposób perfekcyjny podkreśla narrację utworu, w której kapral prowadzony jest na rozstrzelanie [Jachimecki 1983, 51-52].

Zwrócono jednakże uwagę, że warstwa fortepianu w pieśniach Moniuszki nie dochodzi nigdy do wirtuozowskich efektów i nie można jej zestawiać z wirtuozerią Schuberta czy Schumanna. Tłumaczy to zapewne fakt, że ten nie był pianistą, lecz organistą, co wyczuwa się często w stylu akompaniamentu. Nie szukał też nowych środków czy dobierania barw dźwiękowych.

Pomimo tych niedoskonałości podkreśla się jednak, że „jako twórca pieśni stanął Moniuszko obok najwybitniejszych kompozytorów innych narodowości" Jako narodowego kompozytora zestawia się go z Franciszkiem Schubertem, podkreślając, że obaj „dali rodakom bogaty i różnorodny repertuar pieśni, przeznaczonych raczej do śpiewania amatorskiego", a także perfekcyjnie potrafili oddać w melodii dramaturgię tekstu słownego" [Rudziński 1988, 54]. 


\section{Wnioski}

Analiza twórczości pieśniarskiej Stanisława Moniuszki wykazała, że urodzony na kresach wschodnich Rzeczpospolitej wielki polski kompozytor komponując pieśni zawarte w Śpiewniku domowym sięgał po teksty aż 97 twórców (też do innych źródeł). W tym licznym gronie znaleźli się głównie współcześni kompozytorowi poeci, m.in. tak wybitni jak A. Mickiewicz (21 tekstów), W. Syrokomla i wielu innych, podobnie jak Moniuszko związani z ziemiami wschodnimi. Po teksty poetów zagranicznych kompozytor sięgał znacznie rzadziej (20 poetów obcego pochodzenia). W ogólnej liczbie 364 pieśni i duetów 40 stanowią utwory do tekstów autorów z zagranicy. Są nimi: Anglicy, Rosjane, poeci francuscy, dwóch czołowych przedstawicieli niemieckiego romantyzmu, poeta białoruski i inni.

Na szczególną uwagę zasługuje różnorodność gatunkowa Śpiewnika domowego. W 12 tomach tego dzieła znajdziemy romanse i ballady, lirykę miłosną i pieśni dramatyczne, śpiewy i dumy historyczne, piosnki sielskie i dumki, a także piosenki taneczne i wojenne.

Talent Moniuszki przejawiał się głównie w melodyce jego pieśni, która była jakby kwintesencja polskości. Wyrosła na gruncie polskiego folkloru bez preferowania wybranego regionu. W pieśniach równie często występują rytmy poloneza, mazura, kujawiaka jak i krakowiaka. Moniuszko dążył do stworzenia powszechnego repertuaru śpiewaczego, dlatego dbał o prostotę komponowanych utworów.

Bogata i różnorodna twórczość S. Moniuszki odegrała istotną rolę w pielęgnowaniu tożsamości narodowej Polaków pod rządami carów. Przez Białorusinów jest uznawany za kompozytora, który inspiracje twórcze czerpał również z białoruskiej kultury ludowej.

Wysoka ocena wartości artystycznej pieśni, zawartych w Śpiewniku domowym, pozwala postawić Stanisława Moniuszkę obok najwybitniejszych europejskich kompozytorów XIX wieku.

W czasach współczesnych warto propagować twórczość pieśniarską S. Moniuszki ze względu na wartości narodowe, niezwykłą głębię treści zawartych $\mathrm{w}$ tekstach oraz wysoki kunszt kompozytorski. W przeszłości jego dzieła łączyły narody zamieszkujące polsko-wschodniosłowiańskie pogranicze.

\section{Źródła (materiały nutowe)}

Moniuszko S., 1988, Śpiewnik domowy. Antologia pieśni na głos z fortepianem, zeszyt 1, red. E. Nowaczyk, Kraków. 
Moniuszko S., 1988, Śpiewnik domowy. Antologia pieśni na głos z fortepianem, zeszyt 2, red. E. Nowaczyk, Kraków.

Moniuszko S., 1988, Śpiewnik domowy. Antologia pieśni na głos z fortepianem, zeszyt 3, red. E. Nowaczyk, Kraków.

Moniuszko S., 1988, Śpiewnik domowy. Antologia pieśni na głos z fortepianem, zeszyt 4, red. E. Nowaczyk, Kraków.

Moniuszko S., 1988, Śpiewnik domowy. Antologia pieśni na głos z fortepianem, zeszyt 5, red. E. Nowaczyk, Kraków.

Moniuszko S., 1998, Pieśni religijne. Utwory solowe $i$ duety z towarzyszeniem organów lub fortepianu, red. E. Nowaczyk, Kraków.

\section{Literatura}

Bednarek R.W., Maroszek J., 2011, Stanisław Moniuszko i jego podlaski rodowód, Białystok.

Davies N., 1991, Boże igrzysko. Historia Polski, t. I, tłum. E. Tabakowska, Kraków.

Davies N., 1991, Boże igrzysko. Historia Polski, t. II, tłum. E. Tabakowska, Kraków.

Dąbek S., 2011, Twórczość litanijna Stanisława Moniuszki i jej konteksty, Warszawa.

Duszyk K., 2000, Wykaz dzieł Stanisława Moniuszki, [w:] Encyklopedia muzyczna PWM. Część biograficzna, t. 6, red. E. Dziębowska, Kraków, s. 307-327.

Dziębowska E., 2000, Moniuszko Stanisław, [w:] Encyklopedia muzyczna PWM. Część biograficzna, t. 6, red. E. Dziębowska, Kraków, s. 303-335.

Jachimecki Z., 1983, Moniuszko, Kraków.

Klechta J., 2013, Duchowość Moniuszki, Nowy Sącz.

Nowaczyk E., 1954, Pieśni solowe S. Moniuszki. Katalog tematyczny, Kraków.

Prosnak J., 1980, Stanisław Moniuszko, Kraków.

Rudziński W., 1988, Moniuszko i jego muzyka, Warszawa.

Rudziński W., 1957, Moniuszko, Kraków.

Wielka encyklopedia powszechna PWN, t. 1-12, Warszawa 1962-1970.

\section{ON THE CULTURAL BORDERLAND OF POLAND AND BELARUS - LITERARY INSPIRATIONS AND ARTISTIC VALUE OF THE HOME SONGBOOK BY STANISEAW MONIUSZKO}

\section{S U M M A R Y}

The present work focuses on literary inspirations and artistic value of song lyrics included in the twelve-volume anthology of Stanisław Moniuszko's songs known as the Home Songbook. The composer, who was born in the Minsk gubernia during 
the period of Russian partition, maintained strong bond with the Eastern frontier of Poland. The research conducted by the author of this study shows that Moniuszko used the texts created by 97 poets including many artists coming from the Eastern part of Poland (e.g. A. Mickiewicz, J. Czeczot, S. Witwicki, W. Syrokomla, J. Prusinowski etc.); in the collection of 364 songs and duos only 40 lyrics were written by foreign authors. Moniuszko's work, with all their richness and diversity, played an important part in the cultivation of national identity of the Poles living under the Tsar's rule; the Belarussians claim that a great deal of his songs have their roots in Belarusian folk culture. 